\title{
FUTURE PSYCHOLOGISTS EXPERIENCING THE CRISIS OF PROFESSIONAL SELF-DETERMINATION: FEATURES OF MOTIVATIONAL SPHERE
}

\author{
Zlata Rzhevska-Shtefan \\ Volodymyr Vynnychenko Central Ukrainian State Pedagogical University, \\ Kropyvnytsky, Ukraine \\ rzlata@yahoo.com
}

\begin{abstract}
The paper is aimed at identifying the features of the future psychologists' professional learning motivation under the conditions of experiencing the crisis of professional self-determination on the border of the $3^{\text {rd }}$ and $4^{\text {th }}$ year of study. The research was held at the Faculty of Psychology and Pedagogy of Volodymyr Vynnychenko Central Ukrainian State Pedagogical University during the years 2017-2018 and involved $473^{\text {rd }}$ year and $634^{\text {th }}$ year psychology students. The following methods were used: psychodiagnostic techniques "Motivation to study at a higher education institution" by Ilyina and "Personality orientation" by Bas. The data was compared to similar research conducted in the years 2003-2004. The study showed that the psychology students of recent years show more acute signs of experiencing the crisis of professional self-determination and the features of their motivational sphere could be characterised as mostly negative. The characteristic feature of the $3^{\text {rd }}$ year students is high indicators of external motivation: egoistic "self-orientation" combined with dominating motives to obtain a diploma. For the $4^{\text {th }}$ year students, the general decrease in motivation is combined with a trend of cognitive motivation decline. This tendency is mainly typical for the group of students who show an unwillingness to change the decision once made in relation to their choice of profession in spite of having negative attitude thereto. The accumulation of negative trends was interpreted in terms of the eco-facilitation approach as a forthcoming adaptive reaction of the eco-system.
\end{abstract}

Keywords: dominating motives; motivation decrease; professional learning activity; future psychologists; professional selfdetermination crisis.

\section{Introduction}

Research into the problem of motivation of students' professional learning is of a great importance since it is particularly the essence and nature of motivation that mainly directs the learning process and influences its effectiveness. Low motivation to obtain professional knowledge and skills may negatively affect not only the process of getting professional education but also the success of further professionalisation.

For the future psychologists, the influence of motivation on professional learning process is even more significant. Their motivational sphere development becomes a part of their professional self-consciousness and in many ways determines the general preparedness for the self-development and acquiring the desirable personal features, which is crucial for the mastering of psychologist profession.

Investigation of the motivational sphere of students' professional learning itself is a complex objective, which is preconditioned by fundamentality and multidimensionality of the problem of motivation as it is and by the existence of numerous approaches to understanding the essence of motivation.

Analysing various conceptions of motivation Gordeeva (2013) distinguishes three main approaches to understand it. The first is based on the early researches in the realm of achievement motivation and distinguishes among two main types of motives: a tendency to approach success and a tendency to avoid failure. This approach appears to be quite narrow, though contributed much to motivation theory and is still of much interest to the researchers.

The second approach which can be described as phenomenological concentrates on various types of motives description: cognitive, social, communicative, motives of competition, self-esteem, selfimprovement, duty, prestige, wellbeing, etc. Unfortunately, the researcher mentions that the role of those motives in the activity performance was unclear (Gordeeva, 2013).

The third approach suggests the division of all the motives into two categories: inner motives and outer motives for the activity. These two categories were described as being in a constant dichotomy, where inner motives correlate with the interest to the activity itself when outer motives with outer stimulation or pressure.

This approach was further developed within the Self-determination theory of Deci and Ryan (2008), claiming that intrinsic motivation is related to an inborn tendency to strive for novelty and complex challenges, to broaden and train one's possibilities, to research and learn, and that extrinsic motivation is related to external social factors. Further research showed that there are other, more intermediate forms of motivation between these two extremes and that extrinsic motivation can't be reduced only to outer approvals or punishment (Ryan \& Deci, 2017). The researchers identified such extrinsic types as external motivation (approaching rewards or avoiding punishments), introjected motivation (proving oneself worthy or avoiding guilt) and identified motivation (acting to express values). 
Both intrinsic and extrinsic types of motives vary in autonomy - a feeling of complete voluntariness and freedom of choice which is most intensive within intrinsic motivation. That implies that intrinsic and extrinsic motivation do not confront each other, rather they maintain the relations of intertransition, going over from regulation with the help of outer factors to the self-regulation. This idea also enables human beings to be conceptualised as evolving systems, hopefully moving through stages of development toward greater maturation and self-ownership (Sheldon, 2014).

Most recent researches on university students' motivation in the context of self-determination theory were conducted by Gordeeva (2013). The scholar underlines the importance of investigating identified motivation as a unique form because it is an extrinsic motivation (i.e., activity is not done for the sake of the experience itself), but nevertheless, it is also an autonomous motivation (because there is full internal assent to doing the behaviour). Identified motivation represents psychosocial maturity, in which an individual willingly takes on potentially uninteresting tasks because it expresses an important personal commitment. Despite its positivity Sheldon, Osin and Gordeeva (2017) notice that "this motivation is not about having made the choice oneself, but rather about valuing the behaviour, and believing that it is critically important" (p. 1216).

Gordeeva (2016) associates this type of motivation with persons need of self-respect and identifies two sub-types of identified motivation: motivation of respect by other people and motivation of self-respect which has positive correlation with personal persistence The scholar claims that motivation of self-respect "is the best available motivator when intrinsic motivation is weak" (p. 65).

Analysis of researches into motives of future psychologists' professional learning has revealed the existence of a complex problem of intrinsic motivation decline. The problem becomes most acute during the $3^{\text {rd }}$ and the $4^{\text {th }}$ years of training (Fokin, 2005, Kadykova, 2002, Rzhevska-Shtefan, 2007). This problem is directly connected with difficulties of experiencing professional determination crisis which is related to reappraisal of values of the chosen profession. The core of the crisis is student's disillusionment in him/herself, uncertainty as to the choice of the profession.

The results of our research conducted in 2004 showed that desirable motivation is characteristic only of $36,6 \%$ of the $3^{\text {rd }}$ year students and $50 \%$ of the $4^{\text {th }}$ year students (Rzhevska-Shtefan, 2007). These results are consonant to the research of Martyniuk and Varina (2014), who claim domination of motive to obtain diploma and absence of inner personally significant profession choice for the majority the future psychologists from the $1^{\text {st }}$ to the $4^{\text {th }}$ year of study.

Future psychologists' low need for professional growth and lowed professional activity also correlates with a high level of motivation of avoiding failure (Vodolazska, 2015, p. 53), which dominates among the $4^{\text {th }}$ year students (Dniprova, 2014, p 20).

Another worrying tendency is revealed in the research of Tukaev, Vasheka and Dolgova (2013). They showed that psychology students with low motivation for learning and professionally meaningful motives are inclined to emotional burnout. This tendency was confirmed by the research conducted by Tsarkova, Prokofieva and Prokofieva (2016, p.47). According to their data, the vast majority of students-psychologists of the $3^{\text {rd }}$ and $4^{\text {th }}$ year of study demonstrate high and a relatively high level of emotional burnout, while high level of emotional burnout is registered within $10 \%$ of the $3^{\text {rd }}$ year students and $14,3 \%$ of the $4^{\text {th }}$ year students.

To our view, the latest researches in the problem of future psychologists' professional learning motivation show that the problem itself hasn't disappeared. On the contrary, it became more acute and demands further investigations, especially in the period when students experience the crisis of professional self-determination during the third and fourth years of study and most significant shifts in the structure of professional learning motives, both positive and negative, occur.

In view of lack of studies of the processes that occur in motivational sphere of psychology students in this complex transition period and bearing in mind the need for their deeper understanding to enable further psychological assistance, we have set the goal to research into features of motivation of professional learning of future psychologists experiencing the crisis of professional self-determination.

\section{Methods}

The research was held at the Faculty of Psychology and Pedagogy of Volodymyr Vynnychenko Central Ukrainian State Pedagogical University during the years 2017-2018 and involved $473^{\text {rd }}$ year and $634^{\text {th }}$ year psychology students. This research was based on our earlier conducted investigation of psychology students' sense-making motives (Rzhevska-Shtefan, 2007), but at that time quite different phenomena of motivation sphere were in the focus of our attention. The data of our earlier research was used to compare the motivational tendencies within the psychology students who studied at the university in different times. 
We distinguished two main phases of the research. During the first phase of the research, we selected groups of the students who demonstrated the features of professional self-determination crisis. For that purpose we used separate statements related to students' confidence in their professional choice taken from the psycho-diagnostic technique by Ilyina "Motivation to study at a higher education institution":

№9. I feel happy to tell my friends about my future profession. (As it is known, students whose dynamics of experiencing the crisis of professional self-determination is negative would avoid talking about the profession they chose, expressing thereby their negative emotional attitude).

№12. I am confident in my choice of the profession.

№22. I am confident that my profession will give me moral satisfaction and material prosperity in life.

№.49. The profession I am mastering is the most important and promising.

In case of disagreement with all four statements, we diagnosed acute experiencing of the crisis of professional self-determination. This means absolute non-acceptance, rejection of the professional choice which can subjectively be described as "Not mine". Should there be disagreement with three or two statements - personal choice of profession is seriously doubtful. In case of disagreement with one statement only - attitude to the profession chosen is ambiguous.

Then the results obtained in the first phase of the research were compared to the appropriate results of our research conducted in 2003-2004 (Rzhevska-Shtefan, 2007).

In the second phase, the research has been carried into motivational sphere features of the students experiencing the crisis of professional self-determination. Based on the data obtained in processing the results of the mentioned psycho-diagnostic technique "Motivation to study at a higher education institution" by Ilyina, dominating motives of students' learning and vocational activity were defined. As is known, this technique is aimed to determine the level of formation of the following students' motivational sphere components: knowledge orientation, profession orientation and obtaining diploma orientation. Indicators under the three scales ("obtaining knowledge"; "mastering the profession"; "obtaining diploma") permit to form the impression about the placement of corresponding motives in the hierarchy of professional learning motives. Besides, prevalence of the indicators under the first two scales evidences the adequate choice of profession by a student and contentment therewith.

In order to identify the students' dominating need, we applied the psycho-diagnostic technique "Personality orientation" by Bas. The technique allows to build three scales: 1) self-orientation (egoistic need to fulfil personal interests); 2) communication orientation (the need of social approval); 3) activity orientation (needs which can be fulfiled only in some activity). We think that this technique permits to obtain a definite impression about student's professional learning activity orientation as opposed to the orientation at those activities which are related to personal needs or communication needs fulfilment.

Besides, we have studied relations between the crisis experience character of the $3^{\text {rd }}$ and $4^{\text {th }}$ year students and indicators in the scales of the two techniques - "Motivation to study at a higher education institution" by Ilyina and "Personality orientation" by Bas.

\section{Results}

As a result of the research conducted during the $3^{\text {rd }}$ and $4^{\text {th }}$ year of study, we have singled out groups of psychology students who more or less demonstrated uncertainty and discontentment with their professional choice. Such $3^{\text {rd }}$ year group counted $57,4 \%$, and the $4^{\text {th }}$ year group $-69,8 \%$ of the total number of students in the year. While the same groups distinguished in the research of 2004 correspond to $52 \%$ for the $3^{\text {rd }}$ year, and $65,6 \%$ for the $4^{\text {th }}$ year. In general, we can state that the percentage of those who experience professional selfdetermination crisis doesn't differ much with a slight increase of their quantity in recent years.

The results of investigating the character of students' professional self-determination crisis experience are shown in Fig.1.

As we can see, the acute negative dynamics of the crisis experience is most manifested within the representatives of the 2017-2018 sample, especially within the $3^{\text {rd }}$ year students.

At the same time, the group having serious doubts in their own choice is larger in the $4^{\text {th }}$ year of study when the $3^{\text {rd }}$ year students more frequently have the ambiguous attitude towards their profession. That is true for the respondents of both samples, but in the sample 2017-2018, the group of the $3^{\text {rd }}$ year students who have serious doubts in their profession is noticeably less in quantity than the corresponding group in the sample of 2003-2004. The same concerns the group of the $4^{\text {th }}$ year students who have the ambiguous attitude towards the profession. 


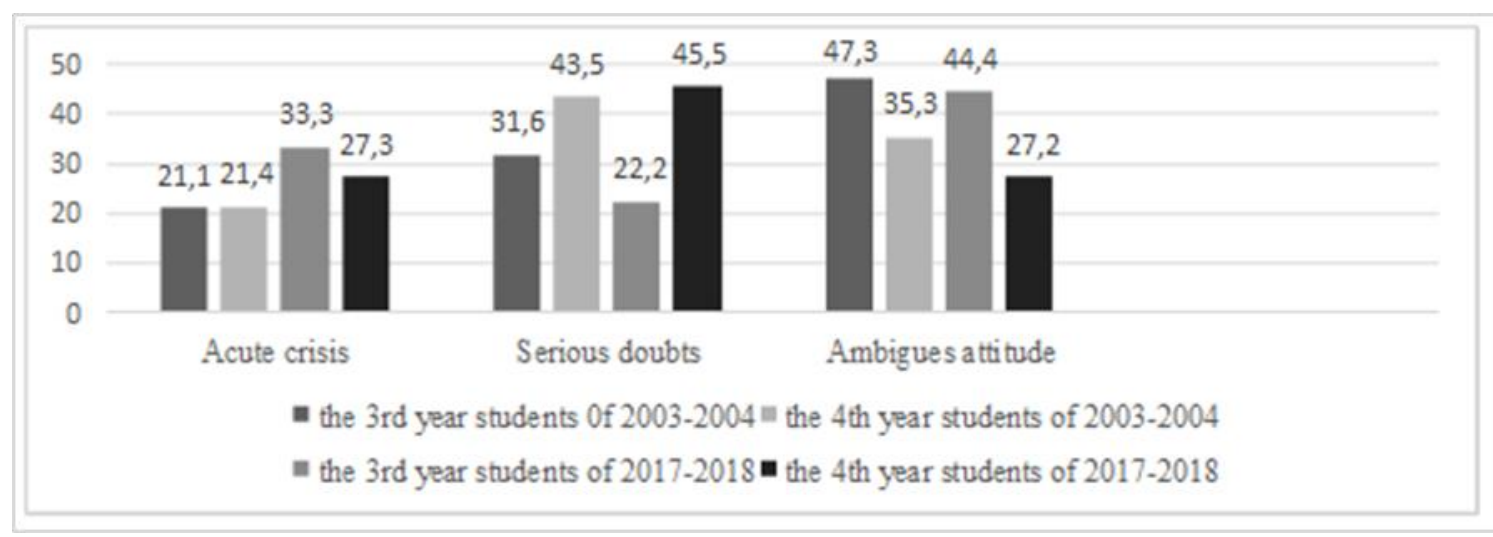

Figure 1. The character of students' experience of professional self-determination crisis

Thus, we can conclude that the respondents of the 2017-2018 sample are more deeply submerged into experiencing the crisis of professional self-determination. The obtained results set us the task of a deeper investigation of the motivational sphere features of the students who belong to this sample.

Further analysis of the data obtained revealed some interesting nuances about the students' experience of the crisis. The group with serious doubts about professional choice is subdivided into three separate subgroups. Subgroup A: students' attitude towards the profession is negative and prejudiced but they declare full confidence in their choice. In our view, it deals with students' unwillingness to change the decision already taken regarding the choice of profession since "so much effort has been invested", or due to individual's volitional self-compulsion which could be described by the saying "you will like it when you get used to it" in cases when he/she had no choice other than this forced by certain material circumstances, etc. Percentage of such students is $11,1 \%$ for the $3^{\text {rd }}$ year and $15,9 \%$ for the $4^{\text {th }}$ year of study.

This kind of students' disposition to our view can be related to identified motivation, described by Gordeeva as motivation of self-respect (Gordeeva, 2016). It is extrinsic by its nature, but nevertheless autonomous and manifests itself mainly in personal persistence in doing ones' activity and thus may positively affect the students' achievements in professional studying.

Subgroup B: students evaluate the profession as being socially important and necessary, but with their attitude thereto being negative and their confidence therein being low. The percentage is the following: 3,7\% - for the 3rd year and 6,8\% - for the 4th year. We associate this group with identified motivation that corresponds to the motivation of respect by others (Gordeeva, 2016). Unlike self-respect motivation it does not contribute to the students' persistence in their mastering future profession and negatively affects their learning process.

Subgroup C: students demonstrate positive emotional attitude towards the profession but have doubts as for their choice, importance of the profession chosen and possibilities to fulfil their material needs. The profession is estimated as "not bad" but it is not clear "whether it suits me". This subgroup totals 7,4\% and $13,6 \%$ in the $3 \mathrm{rd}$ and 4 th year respectively. We associate this disposition with internal contradictions, solving which the students may approach their professional identity.

As we can see the group of those students who demonstrate a negative attitude toward their profession altogether with full confidence in their choice is the largest. The second largest group is of those who are positively configured to their profession but see no future professional perspective for themselves.

Further study of the features of the hierarchy of professional learning activity motives of the psychology students who experience the professional self-determination crisis has revealed the following. Common amongst the $3^{\text {rd }}$ and $4^{\text {th }}$ year students is domination of the motive to obtain a diploma in the hierarchy of professional learning activity motives, which is true for both samples (Table 1).

Table 1

\section{Prevailing motives of professional learning activity of future psychologists experiencing professional self-determination crisis}

$\left.\begin{array}{|l|c|c|}\hline \text { Prevailing motives } & 3^{\text {rd }} \text { year students } & 4^{\text {th }} \text { year students } \\ (\%)\end{array}\right)$


However, amongst the $4^{\text {th }}$ year students, cognitive motives and motives of mastering a profession are more frequent. So, the $3^{\text {rd }}$ year students in the crisis of professional self-determination demonstrate a deeper degradation of professional learning motivation: cognitive and professional motives do not govern their professional learning activity.

Further, we have conducted the research into relations between the character of experience of the crisis by the $3^{\text {rd }}$ and the $4^{\text {th }}$ year students and indicators established by the techniques "Motivation to study at a higher education institution" by Ilyina and "Personality orientation" by Bas.

When estimating the coefficient of linear correlation according to V.Yu. Urbakh, we have disclosed a statistically significant linear correlation between the character of experiencing the crisis by the students of both years of study and the indicators in the scale of "mastering the profession" in the technique "Motivation to study at a higher education institution" by Ilyina. Notably, the more acute the experience of the crisis is, the lower the indicators of professional motivation of the students are.

The 3rd year students reveal a reverse statistically significant linear correlation $(0,05<\mathrm{r}<0,01)$ between the character of experiencing the crisis and indicators in the scale of "direction at oneself" of the technique of "Personality orientation" by Bas. This means that the more acute the student's experience of the crisis is, the higher the indicators of self-orientation are.

The $4^{\text {th }}$ year students reveal a statistically significant linear correlation $(r>0,01)$ between the character of experiencing the crisis and indicators in the scale of "knowledge obtaining motives" in the technique "Motivation to study at a higher education institution" by Ilyina. That is, the more acute a student's experience of the crisis is, the lower his indicators of motivation to obtain knowledge are.

The above-mentioned results of the sample 2017-2018 are exactly equivalent to the results obtained within the sample 2003-2004. To our mind, this implies the existence of some general tendencies in psychology students motivational sphere development in the period of instability generated by professional self-determination crisis.

\section{Discussion}

Our present study is aimed to identify the features of the future psychologists' professional learning motivation under the conditions of experiencing the crisis of professional self-determination on the border of the 3rd and 4th year of study.

According to the results of analyses, half of the $3^{\mathrm{d}}$ year psychology students and more than a half of the $4^{\text {th }}$ year psychology students experience the crisis of professional self-determination. That tendency turned out to be true for two samples - the years 2003-2004 and the years 2017-2018.

Comparing the data of two samples related to different time periods we found out that the psychology students of recent years show more acute signs of experiencing the crisis of professional self-determination.

A characteristic feature for both years of study in both samples is domination of the motive to obtain diploma as well as the positive correlation between the nature of crisis experiencing and indicators of professional motivation: the more acute a student's experience of the crisis is, the lower his indicators of motivation to master the future profession are.

Regardless of degradation of motivation, common amongst all students, while in the crisis of professional self-determination, there are specific features of motivational sphere common among students of the years 2017-2018. For the $3^{\mathrm{d}}$ year students, decrease in professional motivation in the majority of cases coexists with high indicators of "direction at oneself" and domination of motivation to obtain a diploma. Especially this concerns those students who demonstrate acute negative dynamics of the crisis. In our view, their self-direction could be explained by protective mechanisms triggered by negative experiences stemming from professional self-determination crisis. Personal wellbeing, comfort and success become principal for the students. Such attitude preconditions narrowing of the personality sense perspective, escapism, usage of sense regulation predominantly for solving adaptation objectives.

For the $4^{\text {th }}$ year students, negative trends comprise a significant decrease in cognitive motivation. In many cases, it coexists with being "directed at the activity" and concerns those students who demonstrate the unwillingness to change the decision once made in relation to the choice of profession in spite of having a negative attitude thereto. We are inclined to associate this disposition with identified motivation, described by Gordeeva as the motivation of self-respect (Gordeeva, 2016). It is extrinsic by its nature, but nevertheless autonomous and manifests itself mainly in personal persistence in doing ones' activity and thus may positively affect the students' achievements in professional studying.

Another tendency about the $4^{\text {th }}$ year students is the coexistence of low cognitive and professional motivation with being "directed at oneself", which mainly typical for the group of students who doubt their professional adequacy and feel that future profession mismatch with their expectations. We are inclined to 
associate this disposition with internal contradictions, solving which the students may approach their professional identity. Intensification of the above-mentioned doubts in the $4^{\text {th }}$ year, in our view, stems from the first practical attempts by the students and having the first, not always positive, experience of professional activity. As for their cognitive motivation decline, we link it to growing significance of practical skills, mastering which, unlike theoretical knowledge, helps a student to decrease anxiety and uncertainty in relation to his/her professional abilities.

In general, the disclosed features of the $3^{\text {rd }}$ and $4^{\text {th }}$ year students' motivational sphere could be characterised as negative. But, relying upon the eco-facilitation approach suggested by Lushyn (2016), we'd rather interpret the accumulation of these negative trends as a forthcoming adaptive reaction of the ecosystem of each of the students' groups- The third year students demonstrate the signs of stagnation more decrease in developmental rate, efforts to evade completion of the development cycle and uncertainty stemming therefrom. The fourth year students already show a sign of forthcoming change. Particularly, devaluation of theoretical knowledge is a sign of growing value of practical skills, and the increase in the group of those who doubt their professional adequacy - can be a sign of becoming more open to changes and thus, of the beginning of their motivational sphere restructuring.

\section{Conclusions}

The undertaken research showed the complexity of future psychologists' professional learning motivation sphere under the conditions of self-determination crisis during the third and fourth years of studying. The general tendency of professional motivation decline coexists with specific features of motivation both within the $3^{\text {rd }}$ and the $4^{\text {th }}$ year students. Those features correspond to the adaptive reactions used by the students on their way to reconstruct their motivational sphere and achieve the professional identity. The results we obtained in the course of the research may be used to develop corrective programmes for psychological assistance in experiencing the crisis of professional self-determination by the students.

\section{References:}

Vodolazska, O.O. (2015) Samootsinka ta motivatsia dosjagnen' jak chynnyky profesijnogo stanovlennja maibutnih psyhologyv [Selfappraisal and motivation of achievements as factors of future psychologists' professional formation]. Science and education, 10, 49-54. Retrieved 15 September, 2017 from http://scienceandeducation.pdpu.edu.ua/doc/2015/JRN_10/11.pdf

Gordeyeva, T.O., Sychyov, O.A., \& Osin, E.N. (2013). Inner and outer motivation in students: its sources and influences on psychological well-being. Voprosy Psikhologii, 1, 35-45.

Gordeeva, T.O., Ghizitsky, V.V., Sychev, O.A. \& Gavrichenkova, T.K. (2016). Motivation of self-respect and respect by others as factors of academic achievement and persistence in educational activity. Psikhologicheskii Zhurnal, Izdatel'stva Nauka, 37(2), 57-68. Retrieved 15 September, 2017 from https://istina.msu.ru/publications/article/17003252/

Deci, E.L. \& Ryan, R.M. (2008). Self-determination theory: A macrotheory of human motivation, development and health. Canadian Psychology, 49(3), 182-185. https://doi.org/10.1037/a0012801

Dniprova, O.A. (2014). Dynamika motyvatsii dosjagnennia u studentiv psyhologiv [The dynamics of achievement motivation of psychology students]. Visnyk Dnipropetrovslogo universytetu imeni Alfreda Nobelja, Serija "Pedagogika I Psyhologija". Psyhologichni nauky, 7(1), 17-21. Retrieved 18 September, 2017 from http://duan.edu.ua/uploads/psihologi13-14/7432.pdf

Lushin, P. (2016). Neopredelennost kotoruju ne tolerirujut [Ambiguity that is not tolerated] Teoria i praktika psihoterapii, 3(5), 2-6. Retreaved 17 September, 2018 from https://psychotherapy.ruspsy.net/article.php?post=815

Martyniuk, A.G. \& Varina, G.B. (2014). Empirychne doslidzennia protsesu osobystisnogo stanovlennia maibutniogo praktychnogo psyhologa zasobamy geshtalt terapii [Empirical study of the process of future psychologists' personal development by means of geshtalt-therapy]. Science and education, 6, 75-80. Retreaved from http://scienceandeducation.pdpu.edu.ua/uk/arkhiv-zhurnaliv/2014/vipusk-6

Ryan, R.M. \& Deci, E.L. (2017). Self-determination theory: Basic psychological needs in motivation, development, and wellness. New York, NY: Guilford Press. https://doi.org/10.7202/1041847ar

Rzhevska-Shtefan, Z.O. (2007). Formuvannia smysloutvorujuchyh motyviv navchalnoi dijalnosti maibutnih psyhologiv u procesi profesijnoi pidgotovky [Forming future psychologists' sense making motives of studying in the process of professional training]. PhD dissertation, Kirovohrad, Ukraine: Kirovohrad State Pedagogical Unibersity.

Sheldon, K.M., Osin, E.N., Gordeeva, T.O., Suchkov, D. \& Sychev, O. (2017). Evaluating the dimensionality of self-determination theory's relative autonomy continuum. Personality and Social Psychology Bulletin, 43(9), 1215-1238. https://doi.org/10.1177/0146167217711915

Sheldon, K.M. (2014). Becoming oneself: The central role of selfconcordant goal selection. Personality and Social Psychology Review, 18, 349-365. https://doi.org/10.1177/1088868314538549

Tsarkova, O.V., Prokofieva, O.O. \& Prokofieva, O.A. (2016). The study of emotional burnout in students-psychologists and professional psychologists. Science and education, 2-3, 44-49. https://doi.org/10.24195/2414-4665-2016-2-3-9

Tukaiev, S.V. Vasheka, T.M. \& Dolgova, O. (2013). The relationships between emotional burnout and motivational, semantic and communicative features of psychology students. Procedia - Social and Behavioral Sciences, 82, 553-556. https://doi.org/10.1016/j.sbspro.2013.06.308 